\title{
POLITIKK
}

\section{Kim N. Gabrielli og Stina Torjesen (red.): Sosialdemokratisk utenrikspolitikk i Trumps verden Form forlag AS 20I7}

\author{
Anmeldt av Kristian Takvam Kindt \\ Stortinget (SV)
}

Den nye boka om sosialdemokratisk utenrikspolitikk bærer tydelig preg av å være skrevet av folk i Arbeiderpartiet: Den har gode intensjoner og til tider interessante analyser, men har dessverre for lave ambisjoner og er lite nytenkende.

"Vi går en tid i møte som trenger nye løsninger, også i utenrikspolitikken.» Slik åpner konklusjonen fra forfatterne Kim Gabrielli og Stina Torjesen, i den nye boka Sosialdemokratisk utenrikspolitikk $i$ Trumps verden. Forfatterne er begge aktive arbeiderpartifolk med solid erfaring med internasjonale spørsmål. De har sett seg lei på den utenrikspolitiske konsensusen som har preget norsk politisk debatt, og setter seg fore å lage et nytt rammeverk som bryter med vante forestillinger og som skal være solid forankret i sosialdemokratisk ideologi. De håper rammeverket vil «stimulere til kreativ tenking om utenrikspolitikk i Arbeiderpartiet». Dette er et godt utgangspunkt. Det er utelukkende positivt med et bidrag som forsøker å diskutere hvordan vi kan tenke progressivt om et politisk felt preget av konservatisme og en viss frykt for endring.

Forfatterne parafraserer også Karl Marx og det kommunistiske manifest og skriver at «Det går et spøkelse gjennom Europa. Et høyrepopulistisk spøkelse». «Trumps verden", som de kaller det, er en verden der "tett internasjonalt samarbeid mellom stater» ikke lenger er en selvfølge. En verden der «politikerforakt, enorme interne økonomiske og sosiale forskjeller, frykt for å miste jobben, samt uvisshet og pessimisme med tanke på fremtiden danner et viktig bakteppe». Det sosialdemokratiske svaret på dette er mer internasjonalt samarbeid, særlig innen handel og finans og tiltak som skal «adressere ulikhet direkte og med full kraft», ifølge Torjesen og Gabrielli.

For å beskrive nærmere hvordan en sosialdemokratisk utenrikspolitikk bør utformes, konstruerer forfatterne et rammeverk med den overordnede tittelen 
«En bedre organisert kapitalisme». Rammeverket har de tre bærebjelkene «makt og sikkerhet», «bistand» og «vekst og omfordeling». Innen makt og sikkerhet ligger alliansepolitikken, bistand er selvforklarende, mens vekst og omfordeling inkluderer støtte som skal stimulere næringsliv, jobbvekst og utjevning av sosial ulikhet.

Dette er et greit rammeverk, men det er ikke så nytenkende som forfatterne prøver å selge det inn som. Tvert imot er det svært gjenkjennelig. Det er heller ikke noe spesielt «sosialdemokratisk» å tenke i disse baner. Som et talende eksempel la tidligere utenriksminister Børge Brende tre stortingsmeldinger i forrige periode som passer nesten perfekt inn i de tre pilarene til forfatterne. Veivalg-meldingen om sikkerhetspolitikk dekker makt og sikkerhet, den nye utviklingsmeldingen dekker bistand, mens meldingen «sammen om jobben» dekker næringslivssatsingen. Det eneste som skiller dette rammeverket fra den nåværende regjeringens politikk er den eksplisitte vekten på ulikhet.

Ser vi på hvilke viktige politiske grep forfatterne mener må gjøres innen de tre pilarene, er det også mye kjent stoff. Under makt og sikkerhet spør de «hvilke allianser er det Norge har eller kan inngå for å gjøre oss mer robust»? Svaret er velkjent: «Kort og enkelt: NATO og EU». Under bistand mener de at "ytterligere konsentrering rundt utdanning og helse er viktig, og da særlig i og rundt, sårbare og konfliktberørte stater.» Det kunne vært skrevet av Børge Brende eller Ine Marie Eriksen. Under vekst og omfordeling vektlegger de en økt satsing på næringsliv og arbeidsplasser. Det er også tema som er sentrale for Høyre så vel som Arbeiderpartiet.

I tillegg er den tredje pilaren, «vekst om omfordeling» litt tvetydig. Det er her forfatternes vektlegging av ulikhet kommer inn, men samtidig inkluderer pilaren støtte til en aktør som NORFUND og andre næringslivssatsinger, som har blitt kritisert for å ha nettopp for lite fokus på bærekraftig utvikling i sin virksomhet. Det er en reell uenighet i bistandspolitikken hvor mye man skal gi til NORFUND versus for eksempel ILO. For å si litt forenklet: Skal man vektlegge vekst for vekstens skyld, eller skal pengene brukes på å skape inkluderende vekst og utjevning? Her er det partipolitiske konflikter som forfatterne faktisk skjuler ved å slå dette sammen til en og samme pilar.

Etter å ha fremlagt rammeverket forsøker forfatterne å konkretisere ytterligere ved å liste opp en rekke tiltak som skal innebære en «bedre organisert kapitalisme i praksis». Overordnet ønsker forfatterne at Norge skal styrke rollen som pådriver for internasjonalt samarbeid på det økonomiske området, satse mer på arbeid og sysselsetting og en økt vektlegging av finans og oljefondet for å oppnå utviklingspolitiske mål. Mange av de konkrete forslagene her er velkjente, mens enkelte er nytenkende. Likevel er kapittelet mer utgangspunkt for å utvikle politikk, enn faktisk utviklet politikk. Forfatterne innrømmer også dette selv, og mener at listen kan være et utgangspunkt for diskusjon, mer enn ferdigstilte forslag. Det gjør imidlertid at forslagene ikke helt kan kvalifisere til å representere noen ny linje, eller paradigmeskifte, i norsk utenrikspolitisk tenkning.

Selv om flere av forslagene er interessante, savner jeg en diskusjon av de reelle utenrikspolitiske debattene hvor det har vært politisk uenighet de siste årene. Oljefondet diskuteres mye, men det konkrete forslaget som å la oljefondet investere 
i infrastruktur i sør, eller å trekke oljefondet ut av fossil energi diskuteres ikke. De anerkjenner at det er et problem at «Norges statlige relasjoner med omverdenen angår og berører alle norske borgere, men diskuteres og formes av et fătall", men de diskuterer ikke konkrete forslag for å bøte på det. For eksempel nevnes ikke forslaget om å debattere krig i åpent storting heller enn i den lukkede utvidede utenriks- og forsvarskomiteen. De nevner nedrustning, men diskuterer ikke om Norge bør støtte opp om atomvåpenforbudet som nylig ble åpnet for signering i FN. De nevner heller ikke Godal-rapporten om Afghanistan, en av de største evalueringene av norsk krigsdeltagelse noensinne. All den tid de er interessert i å stimulere til utenrikspolitisk debatt, virker det rart å se helt bort fra den faktiske debatten som eksisterer.

Men en mer alvorlig innvending enn at forslagene deres ikke er så radikale og at de ikke fanger opp enkelte eksisterende debatter, er at boken etter mitt syn overser det jeg mener er en helt sentral skillelinje i norsk utenrikspolitikk. Nemlig i hvor stor grad Norge faktisk bør og skal føre en egen og selvstendig utenrikspolitikk, og i hvor stor grad vi skal ta beslutninger uavhengig av alliansepolitiske hensyn. I Dag Einar Thorsens kapittel om utenrikspolitisk historie frem til 1989 sies det treffende at «Norges og Arbeiderpartiets utenrikspolitikk har, (...) for en stor del vært styrt av krefter utenfor landet og partiet. Mulighetsrommet for politikkutvikling på utenriksfeltet har vært sterkt begrenset av større og mektigere lands prioriteringer og samarbeidsmønstre, og av beslutninger fattet på et tidligere tidspunkt». Men refleksjoner rundt hvorvidt dette også er gjeldende i dag finnes det lite av i boka.

Det er mye av Norges utenrikspolitikk som ikke føres ut ifra hva Regjeringen ideelt sett vil, men hva de opplever de må eller er forpliktet til gjennom våre allianseforpliktelser. At Norge sendte stabsoffiserer til Irak, mot norsk opinion, er ett eksempel. Afghanistan-innsatsen er, i alle fall delvis, et annet eksempel. Godal-rapporten om norsk innsats i Afghanistan viser nettopp at det eneste Norge lykkes med var å være en "god alliert» til USA og NATO, men at det var altfor lite debatt om hvorvidt det vi gjorde faktisk var til det beste for Afghanistan. Dersom man har som mål å legge et rammeverk for hvordan norsk utenrikspolitikk burde føres, må det også diskuteres i hvor stor grad man faktisk ønsker å føre en selvstendig utenrikspolitikk i det hele tatt. Det er nesten fraværende i boka.

Det interessante med denne skillelinjen er også at den ikke går utelukkende mellom høyresiden og venstresiden i norsk politikk. Det er nettopp Arbeiderpartiet og Høyre som har representert konsensuslinja om å følge USA og NATO i det meste, mens mindre partier som Venstre og SV er de som har tatt sterkest til orde for en mer uavhengig linje. I den rødgrønne regjeringen var det mange konflikter som satt dette på spissen. Noen ganger lyktes SV i å dra Arbeiderpartiet i en mer selvstendig retning. For eksempel da den rødgrønne regjeringen vedtok å trekke norske styrer ut av Irak, at Norge ble en pådriver for et nytt initiativ om nedrustning eller da vi anerkjente samlingsregjeringen i Palestina. Problemet til boka er at disse diskusjonene ikke trekkes opp som en skillelinje. Det gir et inntrykk av at partiene former sin egen utenrikspolitikk og så gjennomfører den, litt uavhengig av kontekst. En diskusjon om 
det begrensete mulighetsrommet Norge har og hvordan man skal utnytte det best mulig hadde giort boka mer interessant. For den virkelige roten til den utenrikspolitiske konsensusen forfatterne vil ta et oppgiør med er frykten hos særlig Arbeiderpartiet og Høyre for at Norge skal kjøre sin egen linje. Dersom målet til forfatterne er å få Arbeiderpartiet til å tenke nytt i utenrikspolitikken er det etter mitt syn her de må begynne. De må trekke Arbeiderpartiet $\mathrm{i}$ en retning der de tør å ta egne valg. I en verden i rask endring, og med Trump som USAs president, er det viktigere en noensinne.

\section{Om forfatteren}

Kristian Takvam Kindt er politisk rådgiver for SV. Han har tidligere jobbet som forsker på FAFO, med Midtøsten som spesiale. Korrespondanse: kristian.kindt@gmail. com. 